\title{
Distribution of chloroplast DNA variation in British oaks (Quercus robur and $Q$. petraea): the influence of postglacial colonisation and human management
}

\author{
J.E. Cottrell ${ }^{\mathrm{a}, *}$, R.C. Munro ${ }^{\mathrm{b}}$, H.E. Tabbener ${ }^{\mathrm{a}}$, A.C.M. Gillies ${ }^{\mathrm{b}, 1}$, \\ G.I. Forrest ${ }^{\mathrm{a}}$, J.D. Deans ${ }^{\mathrm{b}}$, A.J. Lowe ${ }^{\mathrm{b}, 2}$ \\ ${ }^{\text {a }}$ Forest Research, Northern Research Station, Roslin, Midlothian EH25 9SY, UK \\ ${ }^{\mathrm{b}}$ Institute of Terrestrial Ecology, Bush Estate, Penicuik, Midlothian EH26 OQB, UK
}

\begin{abstract}
Variation in the non-coding region of chloroplast DNA (cpDNA) was studied to determine the route and pattern of postglacial recolonisation of native oak throughout mainland Britain. In total, 1076 mature oak trees of either Quercus petraea (Matt.) Liebl. or Quercus robur L. from 224 British ancient woodland sites were analysed, and represent the largest and most saturating molecular analysis of British oak undertaken to date. The majority of oaks (98\%) possessed one of the three cpDNA haplotypes from lineage B that are commonly found in Spain and western regions of France. Thus, our findings strongly support the hypothesis that most native British $Q$. robur and Q. petraea originate from a Pleistocene refugium in the Iberian Peninsula. A haplotype previously thought to be the result of a de novo postglacial mutation in East Anglia, Native and Nonnative in British Forestry. Proceedings of a Discussion Meeting, March 31-April 2, 1995. University of Warwick, pp. 38-55] was found at several sites in eastern Britain, including major population clusters in East Anglia, Tyneside and northeast Scotland. We propose that this haplotype was introduced to Britain via normal postglacial colonisation processes. Less than $2 \%$ of oak trees sampled possessed haplotypes from lineages which originate from more eastern refugia (Italy and Balkans). Whilst human-mediated translocation may be responsible for the occurrence of these haplotypes in Britain, single long distance dispersal events (of between 300 and $500 \mathrm{~km}$ from France) cannot be excluded for at least one case. The majority of populations sampled (including those where both species are present) were fixed for a single haplotype (69\%). However, significant areas of mixed haplotype woods occurred in the Welsh Marches and Scotland and the proportion of population fixation was lower and intra-population diversity higher for $Q$. robur $\left(G_{\mathrm{ST}}=0.661 ; h_{\mathrm{S}}=0.224\right)$ than for $Q$. petraea $\left(G_{\mathrm{ST}}=0.884 ; h_{\mathrm{S}}=0.089\right)$. The distribution of cpDNA variation in British oak populations is discussed and interpreted in the light of hypothesised recolonisation routes and dynamics, inter-specific hybridisation and chloroplast capture, and human impacts due to the management of ancient woodland. (C) 2002 Elsevier Science B.V. All rights reserved.
\end{abstract}

Keywords: Chloroplast DNA (cpDNA); Quercus robur; Quercus petraea; PCR-RFLP; Phylogeography; Postglacial recolonisation

\footnotetext{
* Corresponding author. Tel.: +44-131-445-2176; fax: +44-131-445-5124.

E-mail addresses: joan.cottrell@forestry.gsi.gov.uk (J.E. Cottrell), alowe@ite.ac.uk (A.J. Lowe).

${ }^{1}$ Current address: Sir Harold Mitchell Building, School of Environmental and Evolutionary Biology,

University of St. Andrews, St. Andrews, Fife KY16 9TH, UK.

${ }^{2}$ Tel.: +44-131-445-4343.
} 


\section{Introduction}

At the height of the last ice-age in Europe, 18,000 BP, numerous plant and animal species were confined to refugia in southern Europe (Dumolin-Lapègue et al., 1997; Taberlet et al., 1998). In Britain at that time, ice sheets extended from the northern part of the country down to south Wales and central England. Areas south of the ice fields were treeless with abundant arcticalpine and steppe vegetation (Godwin and Deacon, 1974), and it is generally accepted that most tree species recolonised the British Isles from Continental Europe (Godwin, 1975). Fossil pollen evidence indicates that oak species were confined to three main Pleistocene refugia in southern Europe, in Iberia, Italy and the Balkans (Huntley and Birks, 1983), and it is believed that oak started to emerge from these refugia as the ice caps began to retreat about 12,000 BP. Subsequently, oak species began to re-enter southern Britain approximately 10,000 BP (Godwin, 1975; Birks, 1989). Although it is not possible to distinguish between oak species on the basis of fossil pollen, only Quercus robur L. and Quercus petraea (Matt.) Liebl. are believed to be native to Britain (Gardiner, 1974).

Chloroplast DNA (cpDNA) has proven to be very informative in determining the historical routes of postglacial colonisation of plant species (Demesure et al., 1996; King and Ferris, 1998; Schaal et al., 1998). cpDNA is a slow mutating, non-recombining, clonally inherited genome (Zurawski et al., 1984; Wolfe et al., 1987) which is maternally inherited in oaks (Whittemore and Schaal, 1991; Dumolin et al., 1995), and thus can be used to trace seed dispersal routes without the complicating issue of pollenmediated gene flow. Indeed, British and European oaks have already been the subject of several cpDNA investigations. Ferris et al. (1993) identified a mutation in a conserved region of the tRNA ${ }^{\text {Leu1 }}$ intron that highlights an east/west divide for both $Q$. robur and $Q$. petraea across Europe. They found that 14 British oak samples possessed the western cpDNA type. A more extensive study, based on restriction digestion of four cpDNA regions amplified for 1412 oak samples from 345 populations throughout Europe, identified 23 different cpDNA haplotypes (Dumolin-Lapègue et al., 1997). These haplotypes could be used to distinguish amongst oak trees originating from the three putative refugia in Iberia, Italy and the Balkans. Britain was represented by fewer than 10 sites in this study, but the results indicated that Britain has most probably been recolonised by oaks descended from those that survived the last ice-age in the Iberian Peninsula. In addition, a population from the border between England and Wales (the Welsh Marches) possessed a haplotype which is common in the Balkan area, and thus it is possible that Britain has been recolonised by oaks from more than one refugium.

Although oak colonised Britain from the continent before the English Channel was flooded (Birks, 1989; Godwin and Deacon, 1974), the exact site of entry is still contentious. The basis of this debate is, in part, due to the variety of ways in which pollen analytical data can be displayed and interpreted. Godwin (1975) expresses palaeontological data in terms of oak pollen as a percentage of total tree pollen and cautions against using low percentages of oak pollen to indicate species presence, as pollen found in many samples at low frequency may reflect long distance pollen transport. However, he considers that at this time oak may have been growing in Hampshire and Norfolk, and oak pollen in excess of $10 \%$ was present in a sample retrieved from land now submerged off the coast of Norfolk, East Anglia. Godwin (1975) supported the idea of an invasion of oak into mainland Britain from the south and east. Birks (1989) expresses pollen data as an isochrone map, where oak is noted as present when pollen is found at sustained high levels in samples (an empirical limit of 250-500 pollen grains per sample was set). On this basis, the first record of oak in Britain was at a site in Cornwall about 9500 BP (Brown, 1977). Both Godwin (1975) and Birks (1989) agreed that colonisation northwards subsequently occurred at a rapid rate of between 350 and $500 \mathrm{~m} \mathrm{yr}^{-1}$ through England, Wales and southern Scotland and slowed to $50 \mathrm{~m} \mathrm{yr}^{-1}$ through central and northern Scotland.

Further molecular work by Ferris et al. (1995a,b, 1997) identified a 13 BP duplication in the tRNA ${ }^{\text {Leu1 }}$ intron of the cpDNA which was largely confined to oaks growing in East Anglia. They believed that this mutation must have arisen after oak had colonised western England and Wales, $9500 \mathrm{BP}$, but prior to its later entry into East Anglia about 8000 BP (Ferris et al., 1995a,b). The subsequent discovery of this mutation in trees growing in Sweden and in sites in NW Scotland and other parts of England was interpreted 
as a result of introductions originating from East Anglia (Ferris, 1996; Ferris et al., 1997). With the current tendency to replant only from local stock, this finding raised considerable interest amongst conservationists as it then seemed possible to identify trees of truly East Anglian provenance. The possibility that other cpDNA mutations could differentiate between native and alien stock in other regions of Britain has been eagerly anticipated.

From the previous studies described above, a number of questions remain unanswered, or have been raised, concerning the postglacial colonisation of oak through Britain: What is the origin of recolonising material and has Britain been colonised by oak from more than one refugium? Can further evidence be supplied to verify the hypothesis that the 'East Anglian' haplotype has arisen de novo since oak entered southeast England, and can other regionally specific cpDNA haplotypes be identified in Britain? Can the distribution of cpDNA variation be used to identify the most likely point(s) of entry of oaks into Britain and can it indicate the dynamics of the subsequent spread of oaks? And finally, what are the consequences of human influence through woodland management on species composition and cpDNA haplotype frequency in British ancient woodlands? To examine these questions in more detail, an intensive study of the distribution of cpDNA variation in $Q$. robur and $Q$. petraea has been undertaken in British ancient woodlands, utilising the informative, previously identified cpDNA mutations of DumolinLapègue et al. (1997).

\section{Materials and methods}

\subsection{Plant material}

A total of 1076 trees were sampled from 224 oak sites throughout Britain. Sampling was confined to the two native species: pedunculate oak $(Q$. robur $\mathrm{L}$.) and sessile oak ( $Q$. petraea (Matt.) Liebl.). To maximise the probability of selecting native trees, sampling was largely confined to ancient woodlands, which are defined here as those appearing on the first ordnance survey maps of Britain. Other samples were obtained from large estates as well as from single, well-known ancient trees. All sites chosen for the study were selected only after extensive discussions with local experts and consultation of relevant literature (Ferris et al., 1995b, 1997; Marren, 1992; Rackham, 1974, 1986). Sampling was mostly undertaken when trees were in leaf, so that they could be assigned to one of three classes on the basis of the leaf characters, $Q$. robur, $Q$. petraea or intermediate, i.e. those displaying hybrid characteristics (Jones, 1959; Cousens, 1963; Rushton, 1983). Where trees were not in leaf at the time of sampling, individuals were labelled as 'unknown'. Whenever possible, five trees were sampled from each population. Samples were taken from the largest, oldest trees in a population at intervals of at least $100 \mathrm{~m}$. Population sampling was done on an approximate $50 \mathrm{~km}$ grid square, although some areas such as the west of Scotland, the Lake District and the Isle of Man have been sampled more intensively (Fig. 1).

\subsection{PCR-RFLP methods}

Total DNA was extracted from peeled fresh bud material using the Qiagen Plant Mini Kit (see manufacturer's description for method) or following the CTAB method of Harris (1995). Four universal cpDNA primer pairs were selected to highlight mutations that distinguished the most common cpDNA haplotypes found by Dumolin-Lapègue et al. (1997). These were TF (primers a and $\mathrm{f}$ located in the $\operatorname{trn} \mathrm{T}$ and $t r n \mathrm{~F}$ regions and amplifying the $t r n \mathrm{~L}$ region; Taberlet et al., 1991); and DT (located in the $\operatorname{trn\mathrm {D}}$ and $\operatorname{trn} \mathrm{T}$ regions), $\mathrm{CD}$ (located in the $\operatorname{trn} \mathrm{C}$ and $t r n \mathrm{D}$ regions), and AS (located in the psa A and trnS regions, Demesure et al., 1995). Conditions for PCR were as for those described by Demesure et al. (1995). Four primer/restriction enzyme combinations were found by Dumolin-Lapègue et al. (1997) to differentiate the nine most common cpDNA haplotypes found in northern Europe; DT and TaqI, AS and HinfI, TF and $A l u \mathrm{I}$, and CD and TaqI. In practise, however, only two of these primer/enzyme combinations (DT*TaqI and $\mathrm{TF}^{*} A l u \mathrm{I}$ ) were necessary to differentiate unambiguously between eight of these haplotypes and so only these two primer/enzyme combinations were used to screen all samples in this study. Restriction digestion of PCR products was performed according to manufacturer's conditions (Gibco BRL) and digested fragments were separated on $8 \%$ polyacrylamide 


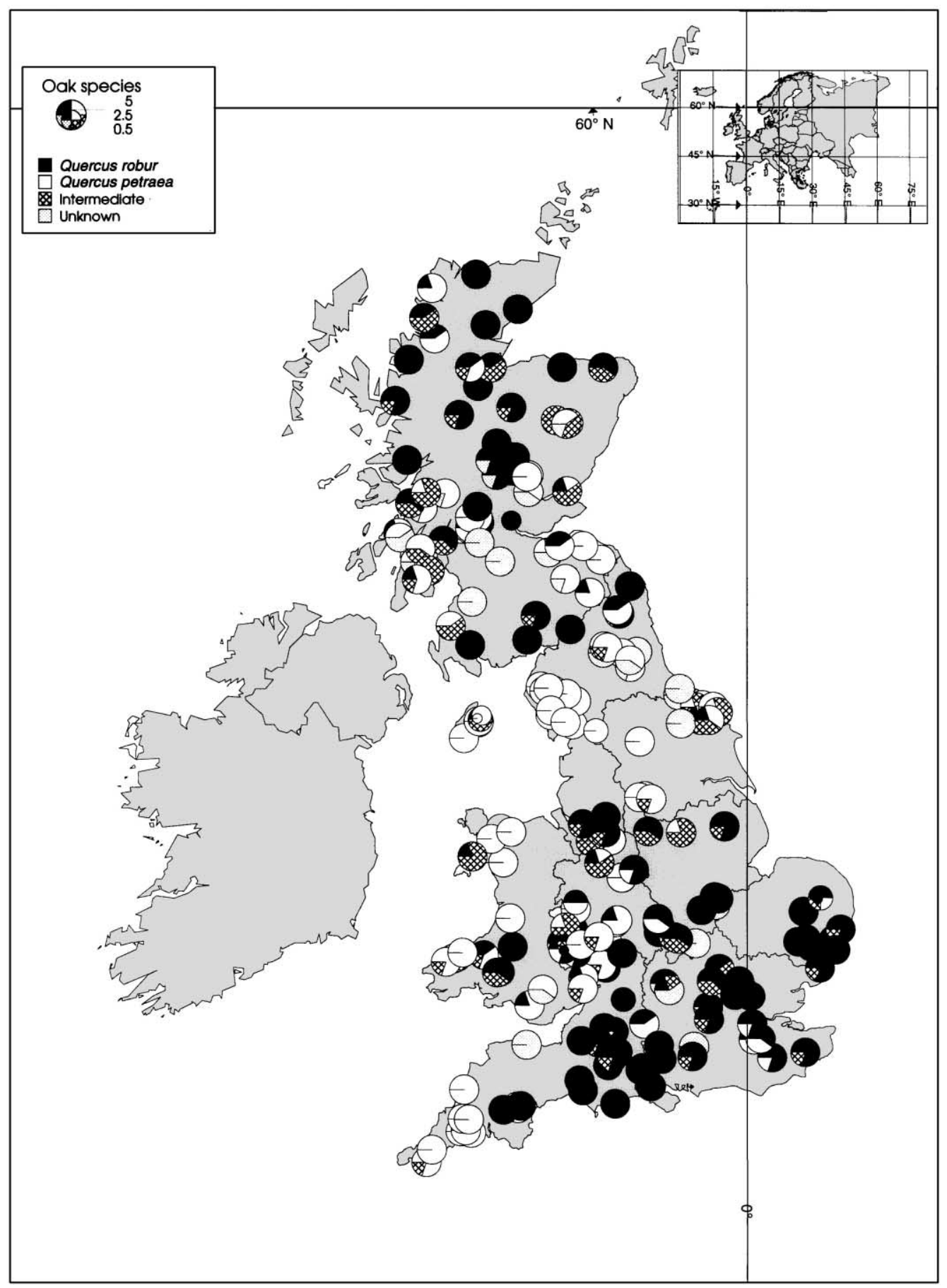

Fig. 1. Distribution of $Q$. robur, Q. petraea and intermediate individuals in sampled British ancient woodlands. Size of pie indicates the number of individuals sampled from each population (from 1 to 5). 
Table 1

Details of cpDNA haplotypes found in British Q. robur and Q. petraea samples and their fragment profile obtained with the specified probe/ enzyme combinations

\begin{tabular}{|c|c|c|c|c|}
\hline & \multicolumn{4}{|c|}{ Primer/enzyme combination ${ }^{\mathrm{a}}$} \\
\hline & \multicolumn{3}{|l|}{$\mathrm{DT}^{*} \operatorname{Taq} \mathrm{I}$} & \multirow[t]{2}{*}{$\mathrm{TF}^{*} A l u \mathrm{I}(2)$} \\
\hline & 1 & 2 & 3 & \\
\hline Type & Point mutation & Insertion/deletion & Insertion/deletion & Insertion/deletion \\
\hline $\begin{array}{l}\text { Approximate fragment } \\
\text { size (BP) }\end{array}$ & $\begin{array}{l}1=690 \\
9=590\end{array}$ & $\begin{array}{l}1=400 \\
2=390\end{array}$ & $\begin{array}{l}1=350,2=335 \\
3=325,4=320\end{array}$ & $\begin{array}{l}1=813, \quad 2=807 \\
3=800\end{array}$ \\
\hline \multicolumn{5}{|l|}{ Haplotype } \\
\hline 1 & 9 & 1 & 2 & 2 \\
\hline 10 & 1 & 2 & 3 & 3 \\
\hline 11 & 1 & 2 & 3 & 1 \\
\hline 12 & 1 & 2 & 4 & 3 \\
\hline 7 & 1 & 1 & 5 & 3 \\
\hline 99 & 1 & 1 & 1 & 3 \\
\hline
\end{tabular}

${ }^{\text {a }}$ Numbers 1, 2 and 3 indicates mutation number.

gels (Hoefer). Gels were stained with $0.5 \mu 1 / \mathrm{ml}$ ethidium bromide and results were recorded using a gel documentation system (Biorad) or photographed with a Polaroid ${ }^{\circledR}$ camera. Individuals were classified for cpDNA haplotype according to the presence or absence of site or length mutations (Table 1). For a full description of the mutations and haplotypes used in this study, see Petit et al. (2002b). Haplotype identity was independently verified by the project collaborators at INRA (R. Petit and A. Kremer) to ensure that the standard haplotype nomenclature of Petit et al. (2002b) was adopted by all project participants. The phylogenetic relationship between haplotypes was assessed by Petit et al. (2002b) and monophyletic groupings of genetically similar haplotypes were assigned to lineages, the lineage nomenclature has been adopted here. Details of location, species composition and haplotype frequency for each of the 224 sample populations are available on request from JEC or AJL.

\subsection{Data analysis}

The species and haplotype frequencies for each population were plotted from geo-coded data using MapInfo Professional Version 4.1 (MapInfo) for the PC. $\chi^{2}$ tests were used to examine the significance of latitudinal differences in species domination and proportion of fixed woodlands and the distribution of haplotypes between species for all woodland samples. Intra-population diversity, total diversity and population subdivision were estimated from raw data using the statistics $h_{\mathrm{S}}, h_{\mathrm{T}}$ and $G_{\mathrm{ST}}$, calculated using a program specifically designed for data derived from the haploid chloroplast genome (Pons and Petit, 1995). As the majority of British samples (98\%) were found to possess one of three equally related haplotypes belonging to a single lineage (Petit et al., 2002b), statistics which take into account genetic distance in the analysis of population subdivision (e.g. $v_{\mathrm{S}}, v_{\mathrm{T}}$ and $N_{\mathrm{ST}}$ ), were not calculated. To examine the overall regional distribution of haplotypes, the frequency of all haplotypes within a $50 \mathrm{~km}$ radius was calculated for each sample location. For radii where one haplotype occurred at a frequency greater than $50 \%$, the proportion of trees possessing that haplotype was presented graphically by plotting variable area circles to reflect proportion of dominance (from 0.5 to 1.0 ) at the centre of radii.

\section{Results}

For all samples, geographic location and species classification, based on leaf characters in Fig. 1. Samples from southern England, stretching from Devon to East Anglia, are dominated by $Q$. robur. Woods dominated by $Q$. robur are also common in 
Table 2

Oak samples classified according to species $\left(Q\right.$. robur, $Q$. petraea, intermediate and unknown) and grouped by latitudinal range $\left(50.0^{\circ} \mathrm{N}-\right.$ $\left.58.9^{\circ} \mathrm{N}\right)$

\begin{tabular}{|c|c|c|c|c|c|c|c|c|c|}
\hline \multirow[t]{2}{*}{ Species } & \multicolumn{9}{|c|}{ Latitude $\left({ }^{\circ} \mathrm{N}\right)$} \\
\hline & $50.0-50.9$ & $51.0-51.9$ & $52.0-52.9$ & $53.0-53.9$ & $54.0-54.9$ & $55.0-55.9$ & $56.0-56.9$ & $57.0-57.9$ & $58.0-58.9$ \\
\hline Q. robur & 40 & 115 & 111 & 25 & 12 & 36 & 51 & 36 & 18 \\
\hline Q. petraea & 42 & 37 & 75 & 25 & 120 & 38 & 41 & 8 & 4 \\
\hline Intermediate & 1 & 22 & 38 & 15 & 28 & 20 & 12 & 17 & 3 \\
\hline Unknown & 5 & 18 & 5 & 9 & 27 & 15 & 5 & 2 & 0 \\
\hline
\end{tabular}

central and northern Scotland. In contrast, samples from the extreme southwest of England, west Wales, central and northern England and southeast and west Scotland are predominantly $Q$. petraea. The latitudinal split in the distribution of the two species was found to be significant (Table $2, \chi^{2}=186$; d.f. $=16$; $P<0.001)$. There were also some notable exceptions to these generalised patterns of distribution, including woods such as Glengallain, in the west of Scotland and Traie de Halsall on the Isle of Man which are woods dominated by $Q$. robur that occur in areas where $Q$. petraea is generally more common. Mixed species woods were found to be almost absent in Cornwall, north Wales and the Lake District, where woods were strongly dominated by $Q$. petraea.

The distribution of cpDNA haplotypes in British material is shown in Fig. 2. The majority of oaks sampled had one of three haplotypes, 10 (27\%), 11 $(20 \%)$ and $12(51 \%)$. These three haplotypes belong to lineage B (Petit et al., 2002b). Less than 2\% of samples did not possess one of these three cpDNA haplotypes. Of the rare haplotypes, haplotype 7, from lineage A (Petit et al., 2002b), was found at Dalkeith Palace near Edinburgh in Scotland, and in four populations from woods in the Welsh Marches near the border between south Wales and England (Hartpury College, Lea and Paget's, Elmley Castle Deer Park and Collinpark Wood). Haplotype 1, from lineage C (Petit et al., 2002b), was found at Windsor near London and Collyweston Great Wood also in the Welsh Marches. A previously uncharacterised haplotype, labelled here as 99, was detected at Duns, near the Scottish border with England, and Bagley, Oxfordshire, in southern England.

Sixteen of the 224 sites were single trees or had been sampled during the winter and therefore could not be assigned to species. Of the remaining 208 woods surveyed, $69 \%$ were comprised of trees possessing the same haplotype (single haplotype woods) and $31 \%$ contained more than one haplotype (mixed haplotype woods, Table 3). Half of all woods surveyed contained only a single species (pure species woods), of which $49 \%$ were pure $Q$. robur and $51 \%$ were pure $Q$. petraea. Within these pure species woods, it was evident that the $Q$. robur component consisted of more mixed haplotype woods (39\%) than the $Q$. petraea component (18\%). Indeed, the value for $h_{\mathrm{S}}$ was greater in $Q$. robur $(0.224)$ than in $Q$. petraea $(0.088)$ indicating higher within population diversity in the former species (Table 4). Within the woods that contained both species, or a single species together with intermediate individuals (mixed species woods), $66 \%$ were comprised of a single haplotype and $34 \%$ were of mixed haplotype. For the mixed species, mixed haplotype woods, where two or more trees of either species had been sampled, it was more common for the $Q$. robur component to have more than one haplotype (84\%) than for the Q. petraea component $(54 \%)$. The distribution of haplotypes was speciesspecific for only $8.5 \%$ of the mixed species, mixed haplotype woods.

Haplotypes have a clustered distribution (Fig. 2), and when both species of oak are considered together, a $G_{\mathrm{ST}}$ test to examine population sub-structuring, indicated very high levels of genetic differentiation between populations $\left(n=217\right.$, Pons $G_{\mathrm{ST}}=0.742 \pm$ 0.027 , Table 4). However, when considered separately, sub-structuring was noticeably higher in $Q$. petraea $\left(n=79\right.$, Pons $\left.G_{\mathrm{ST}}=0.844 \pm 0.041\right)$ than in $Q$. robur ( $n=89$, Pons $\left.G_{\mathrm{ST}}=0.661 \pm 0.047\right)$, complementing the $h_{\mathrm{S}}$ calculation above that $Q$. robur has higher within population diversity than $Q$. petraea.

The level of haplotype dominance in some areas can be seen more clearly in Fig. 3, which also indicates a 


\begin{tabular}{|l|}
\hline Oak Haplotypes \\
\\
$\square$ Haplotype 1 \\
Haplotype 7 \\
Haplotype 10 \\
Haplotype 11 \\
Haplotype 12 \\
New Haplotype \\
\hline
\end{tabular}
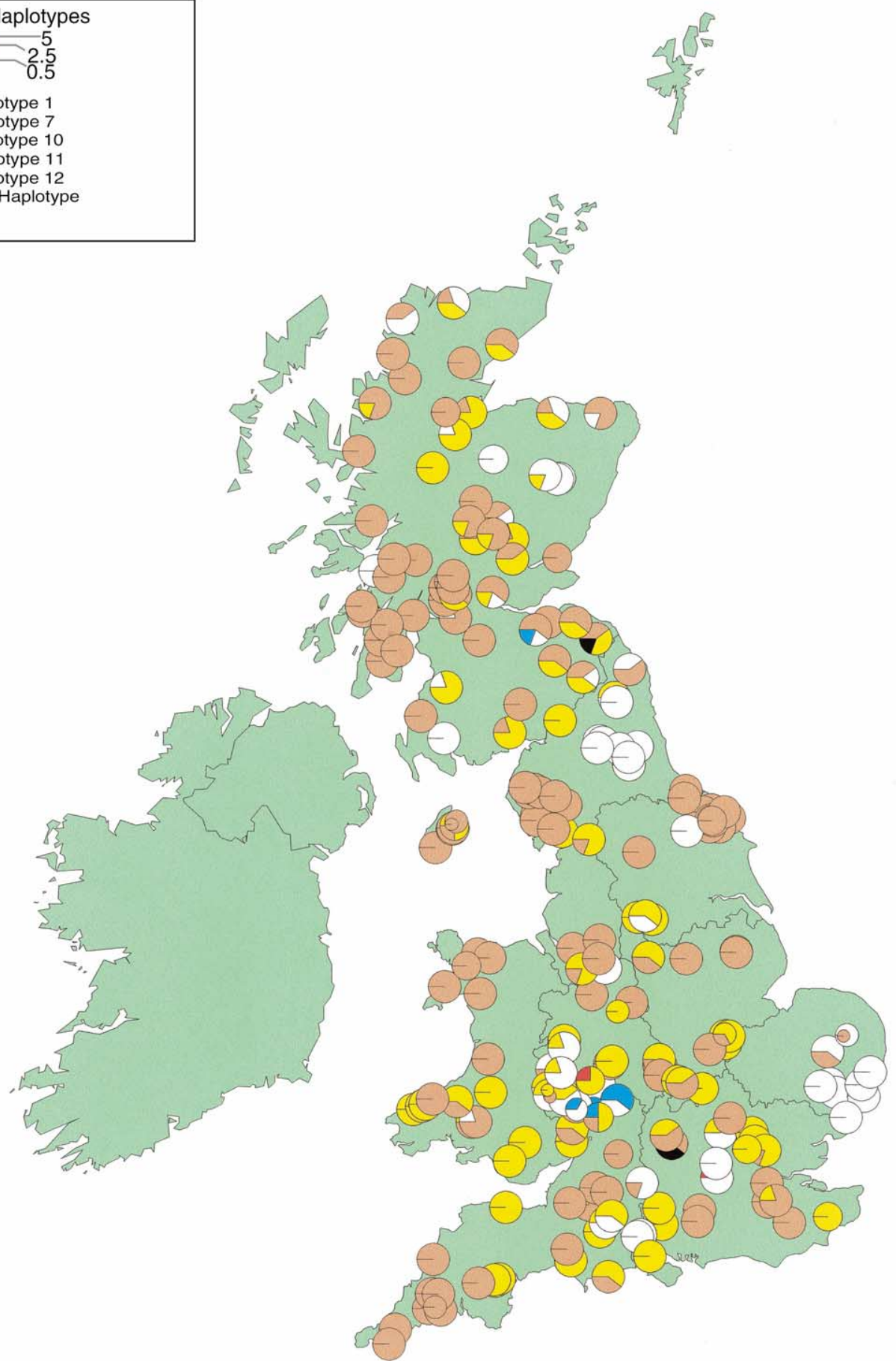

Fig. 2. Distribution and frequency of cpDNA haplotypes within sampled British ancient woodlands. Size of pie indicates the number of individuals sampled from each population (from 1 to 5). 
Table 3

Partitioning of woods by species and haplotype ${ }^{\mathrm{a}}$

\begin{tabular}{ll}
\hline Species and haplotype category & $\begin{array}{l}\text { Number of } \\
\text { sampled woods }\end{array}$ \\
\hline Pure species $(Q$. robur $)$, single haplotype & 31 \\
Pure species $(Q$. robur $)$, mixed haplotype & 20 \\
Pure species $(Q$. petraea $)$, single haplotype & 44 \\
Pure species $(Q$. petraea), mixed haplotype & 10 \\
Mixed species, single haplotype & 68 \\
Mixed species, mixed haplotype & 35 \\
Unknown species & 12 \\
Single tree sites & 4
\end{tabular}

${ }^{a}$ Mixed species woods were classified as those that contained trees of both species plus those containing a single species together with intermediates.

slight longitudinal bias to cpDNA distribution. Haplotype 12 dominated populations near the west coast of Britain, in particular Cornwall, north Wales, Lake District, and the west coast of Scotland although there were also significant clusters around Yorkshire and Kent in the east. Haplotype 11 tended to have a more easterly distribution and dominated East Anglia and Tyneside but also occurred in the south of England, the Welsh Marches, the north of England and at several sites in Scotland. Haplotype 10 tended to be concentrated in populations in south Wales, southern England and central Scotland. Geographic areas also differed in their level of fixation for single cpDNA haplotypes. Woods in East Anglia, Cornwall and Devon, north Wales, the Lake District, Yorkshire and the west of Scotland were dominated by a single haplotype. Conversely, mixed haplotype woods were common in the Welsh Marches and the east and north of Scotland (Fig. 2). The overall proportion of mixed haplotype woodlands was largest at latitudes greater than $55.0^{\circ} \mathrm{N}$ (Table 5).

The distribution of haplotypes differed significantly between the two species (Table 6, $\chi^{2}=33.995$; d.f. $=9 ; P<0.001)$. Haplotype 12 occurred most commonly in $Q$. petraea whereas haplotypes 10 and 11 were more frequent in $Q$. robur. Total diversity $\left(h_{\mathrm{T}}\right)$ of all the sampled populations was 0.629 (Table 4 ) and $h_{\mathrm{T}}$ was greater in $Q$. robur $(0.660)$ than in $Q$. petraea (0.569) (Table 4). However, generalising species distribution across Britain does mask some strong regional patterns. For example, in the south and east of England haplotype 11 was restricted to $Q$. robur whereas it was present in both species in the Welsh Marches. Further north, trees with this haplotype were largely, although not entirely, $Q$. petraea (see Figs. 1 and 2). In addition, it was noticeable that in some areas dominated by a single haplotype, there were occasional woods containing a different haplotype to that of surrounding populations. For example, Glengallain in west Scotland was fixed for haplotype 11 and was

Table 4

Population differentiation $\left(G_{\mathrm{ST}}\right)$, intra-population diversity $\left(h_{\mathrm{S}}\right)$ and total diversity $\left(h_{\mathrm{T}}\right)$ estimates for all British oak populations samples and Q. robur and $Q$. petraea populations independently (where $n>2$ ) (standard errors are shown in parentheses)

\begin{tabular}{llll}
\hline & $G_{\mathrm{ST}}$ & $h_{\mathrm{S}}$ & $h_{\mathrm{T}}$ \\
\hline Both species $(n=217)$ & $0.742(0.027)$ & $0.162(0.018)$ & $0.629(0.017)$ \\
Q. robur $(n=89)$ & $0.661(0.047)$ & $0.224(0.031)$ & $0.660(0.016)$ \\
$Q$. petraea $(n=79)$ & $0.844(0.041)$ & $0.088(0.024)$ & $0.569(0.042)$ \\
\hline
\end{tabular}

Table 5

Number of populations fixed for a single haplotype or of mixed haplotype composition (proportion in parentheses) by latitudinal range $\left(50.0^{\circ} \mathrm{N}-58.9^{\circ} \mathrm{N}\right)$; populations comprising a single sample were excluded $(n=4)$

\begin{tabular}{lccccccccc}
\hline \multicolumn{10}{c}{ Latitude $\left({ }^{\circ} \mathrm{N}\right)$} \\
\cline { 2 - 9 } & $50.0-50.9$ & $51.0-51.9$ & $52.0-52.9$ & $53.0-53.9$ & $54.0-54.9$ & $55.0-55.9$ & $56.0-56.9$ & $57.0-57.9$ & $58.0-58.9$ \\
\hline Type of wood & & & & & & & & & \\
Fixed & $17(94.4)$ & $24(61.5)$ & $29(63.0)$ & $11(73.3)$ & $35(92.1)$ & $14(58.3)$ & $13(59.1)$ & $7(53.4)$ & $2(40.0)$ \\
Mixed & $1(5.6)$ & $15(38.5)$ & $17(37.0)$ & $4(26.7)$ & $3(7.9)$ & $10(41.7)$ & $9(40.9)$ & $6(46.1)$ & $3(60.0)$ \\
\hline
\end{tabular}



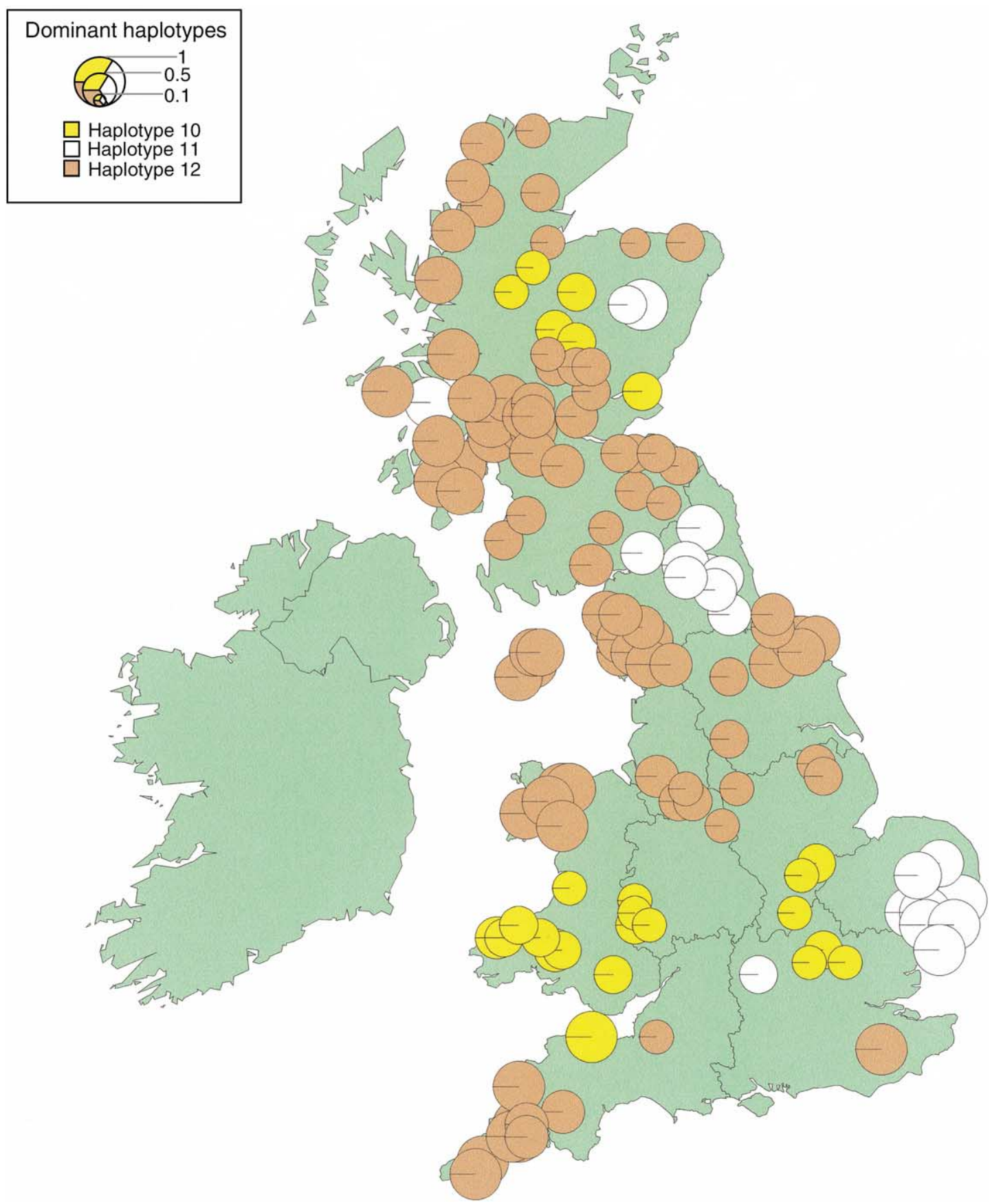

Fig. 3. Plot of haplotype dominated regions of UK calculated for a $50 \mathrm{~km}$ radius for each sample site. The size of pie indicates the proportion of dominance of single haplotypes within an area from 0.5 to 1.0 . 
Table 6

Individual samples classified according to species and haplotype

\begin{tabular}{|c|c|c|c|c|}
\hline \multirow[t]{2}{*}{ Species } & \multicolumn{4}{|c|}{ Haplotype } \\
\hline & 10 & 11 & 12 & Other \\
\hline Q. robur & 141 & 103 & 195 & 5 \\
\hline Q. petraea & 91 & 58 & 234 & 7 \\
\hline Intermediate & 38 & 28 & 85 & 5 \\
\hline Unknown & 28 & 24 & 33 & 1 \\
\hline
\end{tabular}

surrounded by populations fixed for haplotype 12; and Traie de Halsall on the Isle of Man possessed haplotype 10 and was surrounded by populations comprised of haplotype 12 .

\section{Discussion}

\subsection{Distribution of $Q$. robur and $Q$. petraea in Britain}

There has been considerable debate regarding the 'nativeness' of $Q$. robur and $Q$. petraea presently growing in Britain. Extreme views range from both being native (Gardiner, 1974) to both being introduced (Rhind, 1868; Anderson, 1950). Debate has arisen from the fact that there has been considerable planting and management within even the oldest British oak woodlands over the last 300 years (Cousens, 1962; Marren, 1992). Fossil data cannot provide support for either view as oak species cannot be differentiated on the basis of their pollen alone (Gardiner, 1974). However, currently, the most widely accepted view is that both species are native to Britain (Gardiner, 1974).

Overall, the distribution of $Q$. robur and $Q$. petraea sampled in this study of British ancient woods correlates closely with the findings of Gardiner (1974), who states that east of Devon, as well as in certain areas of Scotland, Q. robur is most abundant. In our study, $Q$. petraea was commoner in Wales, Devon and Cornwall, the west of Scotland, the Lake District and Yorkshire. Significant areas of mixed species woodlands and a high incidence of intermediate individuals was also found in southern Scotland and south central England. It was notable that our sample of Scottish woods contained a higher proportion of $Q$. robur material than has previously been recorded by Gardiner (1974). The occurrence of
Q. robur in areas dominated by Q. petraea in Scotland is considered by Cousens and Malcolm (1962) to indicate that $Q$. robur had been introduced to those areas. Thus, the 'natural' status of $Q$. robur in areas of Scotland may therefore be somewhat suspect.

\subsection{Origin of cpDNA haplotypes in British oaks}

The majority of British oak samples (98\%) possessed one of the three haplotypes from lineage B (10, 11 and 12). These haplotypes also occur at high frequency in $Q$. robur and $Q$. petraea sampled from Spain (Olalde et al., 2002) and the western regions of France (Petit et al., 2002a,c). This finding supports the earlier contentions of Ferris et al. (1993, 1995a) and Dumolin-Lapègue et al. (1997) that much of Britain has been colonised by oak material that survived the last ice-age in an Iberian refuge. The previously identified 13 BP duplication in the tRNA ${ }^{\text {Leu1 }}$ cpDNA region (Ferris et al., 1995a,b, 1997), was also screened for in our study and labelled haplotype 11. Ferris et al. (1997) had previously found that this haplotype was confined to $Q$. robur and largely restricted to East Anglia but was not found in their survey of other European material. Ferris et al. (1997) concluded that this haplotype represented a postglacial mutation that must have arisen de novo in an area off the south coast of England before the colonisation of East Anglia. The new findings that this cpDNA haplotype is widespread in Spain (Olalde et al., 2002) and France (Petit et al., 2002a,c) and is phylogenetically closely related to a number of other haplotypes commonly found in Spain (Dumolin-Lapègue et al., 1997; Petit et al., 2002b) indicates that this interpretation is incorrect. It now seems certain that the 'East Anglian' haplotype arose within the Iberian Peninsula prior to the recolonisation of oak through northern Europe. The majority of our samples from East Anglia possess haplotype 11, and where the same populations were sampled, results indicated that haplotype 11 and the 'East Anglian' haplotype are indeed synonymous. There is, however, one notable exception. Kett's oak, a single tree in East Anglia, was classified by Ferris et al. (1997) as 'East Anglian' type but was found in our survey to possess haplotype 12, not haplotype 11. Kett's oak commemorates the Great Rebellion of 1549 and because of the importance that was attached to this event, several trees in Norfolk bear this name (Pakenham, 1996), and 
thus the most likely explanation for this conflicting result is that different Kett's oaks were sampled.

Fewer than $2 \%$ of the British sample contained nonIberian cpDNA haplotypes. Four populations in the Welsh Marches contained haplotype 7 from lineage A, which occurs at high frequency in the Balkans (Petit et al., 2002a), and was also previously recorded in this area by Dumolin-Lapègue et al. (1997). This haplotype has since been discovered in provenance test material originating from seven sites in this area (A. Gillies and A. Lowe, pers. obs.). The closest oaks possessing haplotype 7 are scattered individuals along the north coast of France and in a clustered population near Rennes (300 and $450 \mathrm{~km}$ distance from the Welsh Marches; Petit et al., 2002c). It is possible that the presence of haplotype 7 in the Welsh Marches is the result of a single, long distance colonisation event from the nearest populations, in northern France. However, considering the long history of woodland management in this area, human-mediated translocation of this material could explain its presence. Further sampling of this region will need to be undertaken before the pathway of introduction of this haplotype can be finally elucidated. Similarly, one sample from Dalkeith Wood, near Edinburgh in Scotland possessed haplotype 7. However, for this wood, samples were taken from a native woodland block that occurs close to a patch of managed forest and occurrence of this haplotype is more likely to be the result of human influence.

Samples from two populations in southern England (Windsor, west of London and Collywestern Great Wood, in the Welsh Marches) possessed haplotype 1 from lineage $\mathrm{C}$ which occurs at high frequency in areas of Italy and northwards (Dumolin-Lapègue et al., 1997; Fineschi et al., 2002; Petit et al., 2002a). It seems most probable that this haplotype has been introduced, particularly considering its low frequency $(0.2 \%)$, occurrence in mixed haplotype woods, distance from source populations (in Belgium and the Netherlands, a distance greater than $450 \mathrm{~km}$; Petit et al., 2002a) and the long history of management at Windsor and in the Welsh Marches. A new haplotype (99) was found in samples from Bagley Wood in southern England and Duns in the Scottish borders. This haplotype has not previously been found in $Q$. robur or $Q$. petraea but has been detected in $Q$. suber and $Q$. cerris (R. Petit, pers. commun.; Petit et al., 2002b). There are no substantiated reports of successful crosses being formed between $Q$. suber/Q. cerris and $Q$. robur/Q. petraea and it is known that $Q$. cerris grows in Bagley wood (P. Savill, pers. commun.), thus these samples probably represent misidentified individuals of $Q$. suber or Q. cerris.

\subsection{Pattern and route of postglacial recolonisation}

The three common Iberian haplotypes found in Britain also occur along the entire western portion of France (Petit et al., 2002a,c), and this strongly supports previous assertions that postglacial recolonisation proceeded up the west coast of France before entering southern England (Ferris et al., 1993; Dumolin-Lapègue et al., 1997). There are at least two other Iberian haplotypes which are absent from northern France (Olalde et al., 2002; Petit et al., 2002a,c) and Britain (although one was not screened for). Thus it appears that genetic diversity has been reduced in this species as it has migrated further away from its refugial centre, which is expected due to sampling effects, lineage sorting, drift and population bottlenecks (Hewitt, 1996).

The overall distribution of the common haplotypes indicates some general routes and patterns of oak colonisation through Britain. Haplotype 12 is most common, and occurs mainly in western Britain and is fixed in Q. petraea dominated populations (Cornwall, north Wales, Peak District, Lake District, Isle of Man and southwest Scotland, Fig. 3). The fossil pollen data of Birks (1989) indicate that oak first entered Britain via Cornwall $9500 \mathrm{BP}$ and proceeded north with westerly points slightly leading the colonising edge due to the warming influence of the Gulf Stream. The cpDNA data support this scenario. It is possible that a few oaks, fixed for haplotype 12, first colonised Cornwall from France, where they are common (Petit et al., 2002a,c) and then led the colonisation of Britain up the west coast, dominating woodlands in these areas. However, before more easterly sites could be colonised (apart from perhaps the Tyneside area in northeast England), it appears likely that a second wave of colonising oaks of mixed haplotype swept into southeast England from the continent. There is not such a clear pattern of cpDNA variation on the east coast of Britain. One exception is East Anglia, where populations are dominated by $Q$. robur and are fixed for the relatively rare Iberian haplotype 11 . It is known that 
oak was present in and around Norfolk between 12 and 10,000 BP (Godwin, 1975). The genetic distinctness of this region could also be used to support the idea of an early isolated colonisation of Norfolk by $Q$. robur individuals containing haplotype 11 . The situation in central and northern England and Scotland is more confusing, and apart from the west coast there appears to be little overall pattern of cpDNA distribution.

There is notable clumping of single haplotypes in several areas (Fig. 3, i.e. Cornwall, north Wales, East Anglia, Isle of Man, Lake District, Teeside, Tyneside and southwest Scotland). Such clumped haplotype distribution is typical for a species that disperses in a leptokurtic rather than leading edge or random manner (Hewitt, 1996). For a leptokurtic colonisation model, single long distance dispersal events (most probably by birds carrying acorns) are mainly responsible for colonisation (Ibrahim et al., 1996). A few individuals tend to become established and fixed in populations ahead of the main front of colonisation, which leave tell-tale foot prints in the areas behind the leading front as it can take many generations for later arrivals to penetrate the established community (Hewitt, 1996; Le Corre et al., 1997; Petit et al., 1997). It is interesting to note that the overall proportion of populations fixed for a particular haplotype decreases with latitude, and the mixed nature of these woodlands may indicate a relatively high level of transplanting of local stock within and between Scottish native woodlands (e.g. Tittensor, 1970).

\subsection{Trans-specific sharing of cpDNA haplotypes}

Previous studies of oak species have highlighted the frequency of inter-specific hybridisation and unidirectional chloroplast capture between oak species (Whittemore and Schaal, 1991; Nason et al., 1992; Ferris et al., 1993; Dumolin-Lapègue et al., 1997; Petit et al., 1997). In particular, it has been found that $Q$. robur almost always acts as the maternal parent in artificial crosses between $Q$. robur and $Q$. petraea (Aas, 1991; Steinhoff, 1993). Thus, Q. petraea can capture the chloroplast genome of $Q$. robur through repeated backcrossing to the paternal parent, but the reciprocal event appears to be very rare. This process of chloroplast capture and repeated genetic bottlenecks associated with recolonisation (Hewitt, 1996) has been used to explain the phenomenon that the majority of mixed species, ancient woods are single haplotype (Petit et al., 1997). Indeed, in a survey of 125 mixed species woods from an area in northwest France, 81\% contained a single haplotype. This high proportion of fixation was confirmed in our survey, where $66 \%$ of the 103 mixed species woods surveyed was comprised of a single haplotype.

There is some evidence for species differentiation based on haplotype frequency (haplotype 12 occurred most commonly in $Q$. petraea whereas haplotypes 10 and 11 were more frequent in $Q$. robur), however, this difference was more marked at the regional scale. For example, in the south and east of England, haplotype 11 was restricted to $Q$. robur whereas it was present in both species in the Welsh Marches and largely, although not entirely, in $Q$. petraea further north. Such a pattern may be due to the phenomenon of 'chloroplast capture', however, further analysis would need to be undertaken to rule out other possibilities, e.g. a northerly influx of colonising $Q$. petraea possessing haplotype 11 .

\subsection{Human influence}

Taken together, several lines of evidence from our study suggest that some areas of ancient woodlands have experienced long term and high levels of management and transplanting. One of the major predictions of models that examine the population structure of a maternally inherited, cytoplasmic genome of a leptokurtically dispersed species such as oak is that populations will be fixed for a single haplotype (Hewitt, 1996). Overall, only $31 \%$ of woods are not fixed for a single haplotype. These woods are concentrated in the Welsh Marches and central Scotland, where haplotypes of non-Iberian origin also occur. In both these areas there are also historical records of long term forest management (Holmes, 1975; Anderson, 1967). Central and west coast Scotland has a long history of coppicing for iron smelting (Anderson, 1967), and it is considered by many that $Q$. robur is outside its natural range in such northern localities and therefore must be introduced (Cousens and Malcolm, 1962). Another indication of introduced material is the occurrence of a single wood comprised mainly of a different species and/or haplotype to that of the surrounding area (e.g. Traie de Halsall on the Isle of Man and Glengallain in west Scotland). 
Our survey also found that $Q$. robur exhibited a higher within population diversity $\left(h_{\mathrm{S}}=0.224\right)$ than $Q$. petraea $\left(h_{\mathrm{S}}=0.088\right)$ and that $39 \%$ of pure $Q$. robur woods were of mixed haplotype whereas the proportion was only $18 \%$ for $Q$. petraea. In addition, the level of population sub-structuring is lower in $Q$. robur (Pons $\left.G_{\mathrm{ST}}=0.661\right)$ than $Q$. petraea $\left(\right.$ Pons $\left.G_{\mathrm{ST}}=0.844\right)$. A study undertaken by Dumolin-Lapègue et al. (1999) also found that $Q$. petraea had a higher population $G_{\mathrm{ST}}$ than $Q$. robur ( 0.829 as compared to 0.782 ). This was interpreted to be the result of higher seed flow in $Q$. robur, which is the more pioneering species and believed to be preferred by seed dispersing birds such as jays, due to the more conspicuous nature of its acorns. The $G_{\mathrm{ST}}$ value for $Q$. petraea is very similar between the two studies $(0.844$ for Britain and 0.832 for France), however, the value for $Q$. robur is much lower for British (0.661) as compared to French populations $(0.771)$. It seems most likely that this additional reduction in $G_{\mathrm{ST}}$ within British $Q$. robur is a function of preferential forest management and transplanting of $Q$. robur. It is known that $Q$. robur was the traditionally favoured silviculture species for use as charcoal, timber and pig feed and was therefore more likely than $Q$. petraea to have been planted outside its natural range (Lindsay, 1975; Mabey, 1996).

Such examples highlight the difficulty in interpreting the distribution of cpDNA variation and the confounding effect that human activities can play when trying to unravel natural processes. In our study, it was not possible to confirm unequivocally that any of the woodlands sampled are truly autochthonous, and it has only been possible to maximise this probability by sampling old trees in ancient woods. Assessment of the antiquity of woods is based on both documented records and evidence of past management, e.g. coppicing. However, these indicators do not absolutely guarantee the absence of artificially imported foreign material into a woodland. The difficulty in retaining the viability of seed of broadleaf species over long periods would, however, make it unlikely that there would have been large-scale importation of foreign seed (Gordon, 1998), but this does not rule out the transplantation of local stock from nurseries (Linnard, 1971).

Finally, it should be noted that the three most common haplotypes found in our survey (accounting for more than $98 \%$ of samples) all originate in the Iberian Peninsula. We were not able to identify any
cpDNA markers that are specific to single regions of Britain. The cpDNA haplotypes we surveyed can, however, be used effectively to identify the refugial origin of imported stock, and thus material of Iberian origin can be differentiated from material of eastern European origin. Also in areas where single haplotypes dominate (i.e. Cornwall, north Wales, East Anglia, Isle of Man, Lake District, Yorkshire, Tyneside and west Scotland), oak trees possessing a cpDNA from outside that area can be identified. Thus such markers can be usefully employed to differentiate between planting stock at the local scale. This may become more important in the future, due to current anxiety over the high level of planted stock which is being imported from abroad.

\section{Acknowledgements}

This study has been carried out with financial support from the Commission of the European Communities, Agriculate and Fisheries (FAIR) specific RTD programme, CT-FAIR1 PL95-0297, "Synthetic maps of gene diversity and provenance performance for utilization and conservation of oak genetic resources in Europe". It does not necessarily reflect its views and in no way anticipates the Commission's future policy in this area. The work was also part funded by the Forestry Commission and NERC. We are grateful to Victoria Arandhara, Brian Banks, Izi Banton, Bill Brown, Geoffrey Campion, Stephen Cavers, Robert and Ned Cundall, David Clayden, Dafydd Davies, Judith Derbyshire, Cedric Demeurie, Wally Grice, Tony Hopson, Elsbeth and Maldwyn James, Adrian Jordan, Roger Kay, James Liang, David Mobbs, Steve Minton, Andrew and Duncan Muir, Margaret O'Donnell, Sam Samuel, Martin Sichel, Carolyn Swinsco, Rob Sykes, Geoff Webb, Lisa Weekes and Dave West who helped to collect material and to Andy King and Roger Leakey for helpful comments to the manuscript.

\section{References}

Aas, G., 1991. Crossing experiments on pedunculate and sessile oak (Quercus robur L. and Q. petraea (Matt.) Leibl.). Allg. Forst Jagdztg. 162, 141-145.

Anderson, M.L., 1950. The Selection of Tree Species. Oliver \& Boyd, Edinburgh. 
Anderson, M.L., 1967. A History of Scottish Forestry, Vol. 1. Thomas Nelson \& Sons, London, pp. 572-573.

Birks, H.J.B., 1989. Holocene isochrone maps and patterns of treespreading in the British Isles. J. Biogeog. 16, 503-540.

Brown, A.P., 1977. Late-devonsian and Flandrian vegetational history of Bodmin Moor. Cornwall. Phil. Trans. Roy. Soc. B 276, 251-320.

Cousens, J.E., 1962. Notes on the status of the sessile and pedunculate oaks in Scotland and their identification. Scot. Forest. 16, 170-179.

Cousens, J.E., 1963. Variation of some diagnostic characters of the sessile and pedunculate oaks and their hybrids in Scotland. Watsonia 5, 273-286.

Cousens, J.E., Malcolm, D.C., 1962. Oak population studies in Scotland. Part II. Distribution of Quercus petraea (Matt.) Liebl. and $Q$. robur L. Report on Forestry Research. Forestry Commission, pp. 127-129.

Demesure, B., Sodzi, N., Petit, R.J., 1995. A set of universal primers for amplification of polymorphic non-coding regions of mitochondrial and chloroplast DNA in plants. Mol. Ecol. 4, 129-131.

Demesure, B., Comps, B., Petit, R.J., 1996. Chloroplast phylogeography of the common beech (Fagus sylvatica L.) in Europe. Evolution 50, 2515-2520.

Dumolin, S., Demesure, B., Petit, R.J., 1995. Inheritance of chloroplast and mitochondrial genomes in pedunculate oak investigated with an efficient PCR method. Theor. Appl. Genet. 91, 1253-1256.

Dumolin-Lapègue, S., Demesure, B., Fineschi, S., Le Corre, V., Petit, R.J., 1997. Phylogeographic structure of white oaks throughout the European continent. Genetics 146, 1475-1487.

Dumolin-Lapègue, S., Kremer, A., Petit, R.J., 1999. Are chloroplast and mitochondrial variation species independent in oaks? Evolution 53, 1406-1414.

Ferris, C., 1996. Ancient history of the common oak. Tree News (Autumn), 12-13.

Ferris, C., Oliver, R.P., Davy, A.J., Hewitt, G.M., 1993. Native oak chloroplasts reveal an ancient divide across Europe. Mol. Ecol. 2, 337-344.

Ferris, C., Oliver, R.P., Davy, A.J., Hewitt, G.M., 1995a. Using chloroplast DNA to trace postglacial migration routes of oaks into Britain. Mol. Ecol. 4, 731-738.

Ferris, C., Davy, A.J., Hewitt, G.M., 1995b. Introduced provenances and translocations: the differentiation between native and non-native oaks in Europe. In: Radcliffe, P.R. (Ed.), Native and Non-native in British Forestry, Proceedings of a Discussion Meeting, March 31-April 2. University of Warwick, pp. 38-55.

Ferris, C., Davy, A.J., Hewitt, G.M., 1997. A strategy for identifying introduced provenances and translocations. Forestry 70, 211-222.

Fineschi, S., Taurchini, D., Grossoni, P., Petit, R.J., Vendramin, G.G., 2002. Chloroplast DNA variation of white oaks in Italy. For. Ecol. Manage. 156, 103-114.

Gardiner, A.S., 1974. A history of the taxonomy and the distribution of the native oak species. In: Morris, M.G., Perring, F.H. (Eds.), The British Oak. The Botanical Society of the British Isles, Cambridge, pp. 3-26.
Godwin, H., 1975. The History of the British Flora, 2nd Edition. Cambridge University Press, Cambridge.

Godwin, H., Deacon, J., 1974. Flandrian history of oak in the British Isles. In: Morris, M.G., Perring, F.H. (Eds.), The British Oak. The Botanical Society of the British Isles, Cambridge, pp. 51-61.

Gordon, A., 1998. Whence British trees? Tree News (Autumn), 15.

Harris, S.A., 1995. Systematics and randomly amplified polymorphic DNA in the genus Leucaena Benth. (Mimosoideae, Leguminosae). Plant Syst. Evol. 197, 195-208.

Hewitt, G.M., 1996. Some genetic consequences of ice ages and their role in divergence and speciation. Biol. J. Linn. Soc. 58, 247-276.

Holmes, G.D., 1975. History of forestry and forest management. Phil. Trans. Roy. Soc. London B 271, 69-80.

Huntley, B., Birks, H.J.B., 1983. An Atlas of Past and Present Pollen Maps of Europe, 0-13,000 Years Ago. Cambridge University Press, Cambridge.

Ibrahim, K.M., Nichols, R.A., Hewitt, G.M., 1996. Spatial patterns of genetic variation generated by different forms of dispersal during range expansion. Heredity 77, 282-291.

Jones, E.W., 1959. Biological flora of the British Isles: Quercus. J. Ecol. 47, 166-222.

King, R.A., Ferris, C., 1998. Chloroplast DNA phylogeography of Alnus glutinosa (L.). Gaertn. Mol. Ecol. 7, 1151-1161.

Le Corre, V., Machon, N., Petit, R.J., Kremer, A., 1997. Colonisation with long distance seed dispersal and genetic structure of maternally inherited genes in forest trees: a simulation study. Genet. Res., Camb. 69, 117-125.

Lindsay, J.M., 1975. The history of oak coppice in Scotland. Scot. Forest. 29, 87-93.

Linnard, W., 1971. Thomas Johnes (1748-1816): pioneer of upland afforestation in Wales. Forestry 44, 135-143.

Mabey, R., 1996. Beech family Fagaceae. In: Flora Britannica. Chatto and Windus, London, p. 77.

Marren, P., 1992. The Wild Woods: A Regional Guide to Britain's Ancient Woodland. Nature Conservancy Council, Devon.

Nason, J.D., Ellstrand, N.C., Arnold, M.L., 1992. Patterns of hybridization and introgression in populations of oaks, manzantias and irises. Am. J. Bot. 79 (1), 101-111.

Olalde, M., Herrán, A., Espinel, S., Goicoechea, P.G., 2002. White oaks phylogeography in the Iberian peninsula. For. Ecol. Manage. 156, 89-102.

Pakenham, T., 1996. Meetings with Remarkable Trees. Weidenfield and Nicolson, Ltd., London, pp. 114-115.

Petit, R.J., Pineau, E., Demesure, B., Bacilier, R., Ducousso, A., Kremer, A., 1997. Chloroplast DNA footprints of postglacial recolonization by oaks. Proc. Natl. Acad. Sci. USA 94, 999610001.

Petit, R.J., Brewer, S., Bordács, S., Burg, K., Cheddadi, R., Coart, E., Cottrell, J., Csaikl, U.M., van Dam, B.C., Deans, J.D., Fineschi, S., Finkeldey, R., Glaz, I., Goicoechea, P.G., Jensen, J.S., König, A.O., Lowe, A.J., Madsen, S.F., Mátyás, G., Munro, R.C., Popescu, F., Slade, D., Tabbener, H., de Vries, S.M.G., Ziegenhagen, B., de Beaulieu, J.-L., Kremer, A., 2002a. Identification of refugia and postglacial colonization routes of European white oaks based on chloroplast DNA and fossil pollen evidence. For. Ecol. Manage. 156, 49-74. 
Petit, R.J., Csaikl, U.M., Bordács, S., Burg, K., Coart, E., Cottrell, J., van Dam, B.C., Deans, J.D., Dumolin-Lapègue, S., Fineschi, S., Finkelday, R., Gillies, A., Glaz, I., Goicoechea, P.G., Jensen, J.S., König, A., Lowe, A.J., Madsen, S.F., Mátyás, G., Munro, R.C., Pemonge, M.-H., Popescu, F., Slade, D., Tabbener, H., Taurchini, D., de Vries, S.M.G., Ziegenhagen, B., Kremer, A., 2002b. Chloroplast DNA variation in European white oaks: phylogeography and patterns of diversity based on data from over 2600 populations. For. Ecol. Manage. 156, 5-26.

Petit, R.J., Latouche-Hallé, C., Pemonge, M.-H., Kremer, A., 2002c. Chloroplast DNA variation of oaks in France and the influence of forest fragmentation on genetic diversity. For. Ecol. Manage. 156, 115-129.

Pons, O., Petit, R.J., 1995. Estimation, variance and optimal sampling of gene diversity. I. Haploid locus. Theor. Appl. Genet. 90, 462-470.

Rackham, O., 1974. The oak tree in historic times. In: Morris, M.G., Perring, F.H. (Eds.), The British Oak. The Botanical Society of the British Isles, Cambridge, pp. 62-79.

Rackham, O., 1986. The History of the Countryside. J.M. Dent and Sons, London.

Rhind, W.A., 1868. A History of the Vegetable Kingdom. Blackie and Sons, London.

Rushton, B.S., 1983. The analysis of variation of leaf characters in Quercus robur L. and Quercus petraea (Matt.) Liebl.
Population samples from Northern Ireland. Irish Forest. 40, 52-77.

Schaal, B.A., Hayworth, D.A., Olsen, K.M., Rauscher, J.T., Smith, W.A., 1998. Phylogeographic studies in plants: problems and prospects. Mol. Ecol. 7, 465-474.

Steinhoff, S., 1993. Results of species hybridisation with Quercus robur L. and Quercus petraea (Matt.) Leibl. Ann. Sci. For. 50, 137-143.

Taberlet, P., Gielly, L., Bouvet, J., 1991. Universal primers for amplification of three non-coding regions of chloroplast DNA. Plant Mol. Biol. 17, 1105-1109.

Taberlet, P., Fumagalli, L., Wust-Saucy, A.-G., Cossons, J.-F., 1998. Comparative phylogeography and postglacial colonisation routes in Europe. Mol. Ecol. 7, 453-464.

Tittensor, R.M., 1970. History of the Loch Lomond oakwoods. Scot. Forest. 24, 100-118.

Whittemore, A.T., Schaal, B.A., 1991. Interspecific gene flow in sympatric oaks. Proc. Natl. Acad. Sci. USA 88, 2540-2544.

Wolfe, K.H., Li, W.-H., Sharp, P.M., 1987. Rates of nucleotide substitution vary greatly among plant mitochondrial, chloroplast and nuclear DNA. Proc. Natl. Acad. Sci. USA 84, 9054 9058.

Zurawski, G., Clegg, M.T., Brown, A.H.D., 1984. The nature of nucleotide divergence between barley and maize chloroplast DNA. Genetics 106, 735-749. 